\title{
EXPERIMENTAL INVESTIGATION OF COMPOSITE DECK SLAB WITH CASTELLATED BEAM
}

\author{
Sukanya M \\ Assistant Professor, Department. of Civil Engineering, \\ Karpagam College of Engineering, Coimbatore, India.

\section{Balakrishnan C} \\ Research Scholar, National Institute of Technical Teachers \\ Training and Research, Chennai, India

\section{Devanathan K} \\ Project Engineer, United alliance general contracting, Abu Dhabi.
}

\begin{abstract}
Deck slab with profiled sheeting turns to be an optimal choice in the construction of composite floor system. This thesis is focused on performance of profiled deck slab over steel castellated beam. The castellated beam was fabricated by expanding a standard rolled shape in a manner which creates a regular pattern of holes in the web. Modelling and analysis of composite deck slab with castellated beams will be done by ANSYS software and the single test specimen of castellated beam and composite deck slab with appropriate scale is casted. Concrete grade of M30 and hot rolled steel is adopted for beam section and then cold form steel is adopted for profiled sheet. Stud type shear connector is employed which promotes the composite action at the interface of steel and concrete. Therefore, an experimental test is carried out to investigate the load carrying capacity under cyclic loading. In terms of theoretical and experimental techniques, performance of composite deck slab will be analyzed. From the results it has proven that the composite deck slab over castellated beam section increases the load carrying capacity than other type composite deck system.
\end{abstract}

Keywords: Composite slab, Shear connectors, corrugated sheet, castellated beam, composite action, Embossment

Cite this Article: Sukanya M, Balakrishnan C and Devanathan K, Experimental Investigation of Composite Deck Slab with Castellated Beam. International Journal of Advanced Research in Engineering and Technology, 10(5), 2019, pp. 55-64.

http://iaeme.com/Home/issue/IJARET?Volume $=10 \&$ Issue $=5$ 


\section{INTRODUCTION}

Composite construction in commercial building has been well established in many countries over past few decades, and steel frames with hot rolled or fabricated sections and precast concrete or composite slabs provide an effective means of fast-track construction with column free office spaces. Composite members exhibit enhanced strength and stiffness when compared to the contribution of their components acting separately, and represent a competitive structural solution in many civil engineering applications, such as bridges and buildings etc.

In steel buildings, the use of high-strength or light-gauge (16 to 20 gauge) metal deck with concrete topping has become the standard floor-framing method. The metal deck has embossments pressed into the sheet metal to achieve composite action with the concrete topping. Once the concrete hardens, the metal deck act as the bottom tension reinforcement while the concrete acts as a compression reinforcement. The resulting composite slab acts as a diaphragm providing for the horizontal transfer of shear forces to vertical bracing elements.

\subsection{Composite deck slab}

The term 'composite steel deck slab' means that there is a provision in the system for bonding between the steel deck and the concrete by some mechanical means. In other words, for the steel deck and concrete to act compositely, a mechanical interlocking is needed. This is provided essentially by various 'shear transferring devices' such as rolled embossments, transverse wires, holes etc.

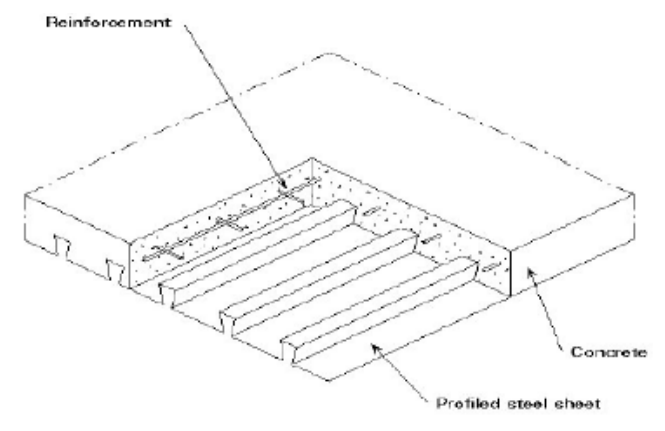

Figure 1.1 composite deck slab

In a concrete filled steel deck, concrete is the stiffest part of the system in the horizontal plane. Therefore the shear stresses are primarily resisted by concrete. Thus, for transmission of force between a steel-column and the diaphragm, forces must first transfer to the beam through the beam-column connection and then to concrete fill either through welded studs or through puddle welds to the steel deck and finally through the bond and the embossment of the decking to the concrete fill. Each of these transfers must be adequate for the intended forces. When the concrete fill connects directly to concrete shear walls or steel encased composite concrete beams, reinforcing dowels can be used for direct shear transfer.

\subsection{Castellated Beam}

A castellated beam is a flexural member whose performance is analogous to that of a vierendeel truss. Castellated beams, figure1.1, are produced by expanding rolled structural beams into deeper sections which results in greater load-carrying capacity without increasing the weight of the beam. They are made economically by flame cutting a single rolled wide flange beam in a definite pattern and then rejoining the segments in such a way as to have a number of openings in its web of the beam. The new section with holes will have a depth at least $50 \%$ more and its section modulus increased by 2.25 times the original section. Castellated beams have a number of specific possibilities and advantages, they are light, cheap, relatively high resistance, and can 
be assembled fast at construction site. The openings in the web permit easy installation of utilities. The castellated beam has the disadvantages of reduced shear capacity due to stress concentrations near the openings. This can be alleviated to some extent by making closer to neutral axis and making the cuts in a wavy number.

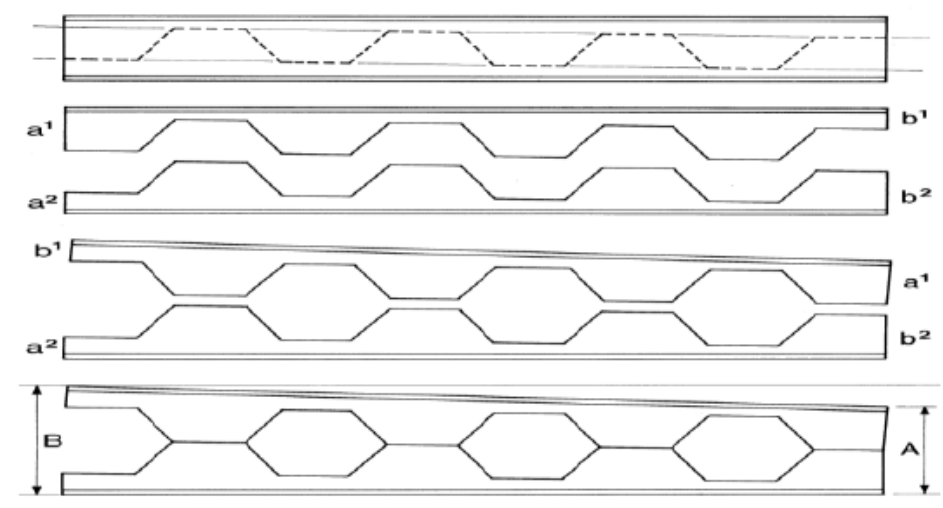

Figure 1.1 Segmentation mode

\section{REVIEW OF LITERATURE}

Crisinel and Marimon [2] have presented a new design approach for the prediction of composite slab behaviour. In this project, a new approach called New Simplified Method is used to obtain the moment-curvature relationship at the composite slab's critical cross section. The New Simplified Method facilitates the calculation of the load-carrying capacity of composite slabs by considering three phases of the $\mathrm{M}$-ø behaviour observed in composite slab critical crosssections. It requires knowledge of the geometric dimensions of the slab, the material properties (steel and concrete) and the characteristic behaviour of the steel-concrete connection as determined based on tests on small-scale specimen.

Evans and Wright [8] and Wright et al. [9] have carried out more than 200 tests on composite deck slab elements and compared the results with the available design methods. They have studied the aspects of construction phase, composite slab action phase and the composite beam action phase in detail. The studies have shown that the variation in concrete strength has little effect on the ultimate load capacity. The crucial parameter that has significant effect on the ultimate strength is the height of the embossment. They have concluded that though the present design procedures are safe, they are very conservative in certain cases. They have recommended that the system as a whole, namely, slab span, beam span and stud connectors, should be considered for obtaining maximum economy in design.

Baskar R et al. [2] has done work on moment curvature and load-deflection relationships of composite steel deck with and without embossment of reinforced slab systems .Cold formed steel deck sections are used in many composite floor slab applications wherein the steel deck serves not only as the form for concrete during construction, but also the principle tensile reinforcement for the bottom fibers of the composite slab. The term composite steel deck floor slab is applied to system in which the steel deck has some mechanical mean of providing positive interlocking between the deck and the concrete. In this paper the mechanical interlocking is achieved through embossment. The flexural behavior of the composite deck slab with and without embossments is assessed by flexure test suggested by Eurocode.4. Four numbers of composite slabs with embossment and three numbers of slab without embossment are tested in laboratory and the results are compared. A description of the applicable failure modes, of the performance test procedures and of the necessary design equations and considerations are presented in this paper. 


\section{FABRICATION PROGRAM}

The size of the test specimen of composite deck slab is adopted as a span of $1.35 \mathrm{~m}$ and width of $0.75 \mathrm{~m}$. The fabrication of the entire composite deck system was done by shop welding. Profiled decking sheet as shown in fig 3.1 was brought from the local distributor with thickness of $1.2 \mathrm{~mm}$ and the schematic diagram of the profiled sheet is shown in fig 3.2.

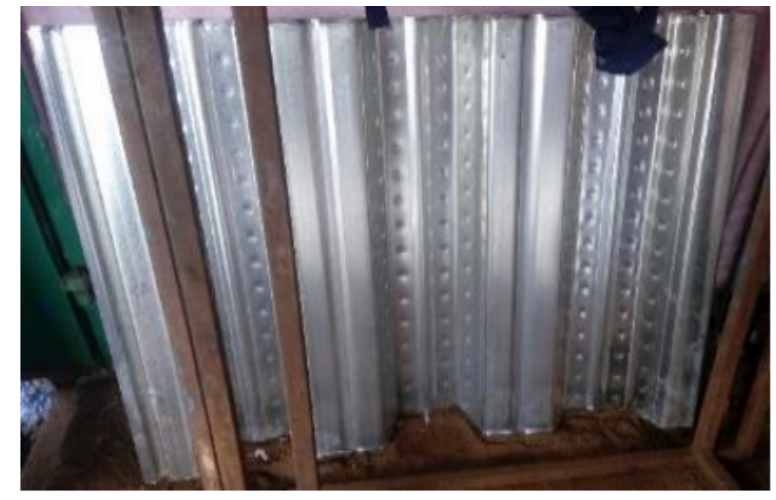

Figure 3.1 Profiled steel sheet

Dimple or embossments is provided at regular intervals all over the flange and web region of the steel sheet which will offers mechanical interlock between steel and concrete. The contribution of shear connectors is to create composite action between concrete and profiled sheet, it controls the two major functional behavior of the slab that is transmission of longitudinal force along the contact surface without slip and then prevention of vertical separation of the in-situ RC slab from the prefabricated structural beam. In this study flexible type shear connector in the form of studs are used in steel-concrete composite slab. M19x100 hexagonal bolt confirming to IS: 11384-1985 is adopted as shear connector and it is welded on the flanged portion of the structural beam, figure 3.4.

ISMB 200 is employed as a parent section for fabricating of castellated. The fabricated castellated beam is made such that the depth of beam is reaches within 1.5 times the original depth of parent section, here the depth increased up to 1.3 times for considering the serviceability requirement, refer fig 3.3. Depth of throat, depth of web openings is agreed to the criteria given by INSDAG. The overall deck system after welding process is shown in figure 3.4

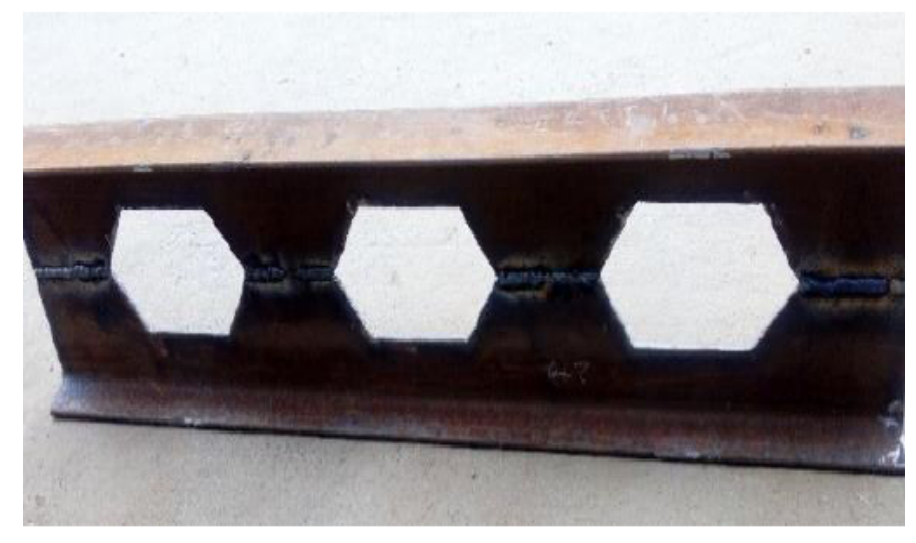

Figure 3.3 Castellated beam 


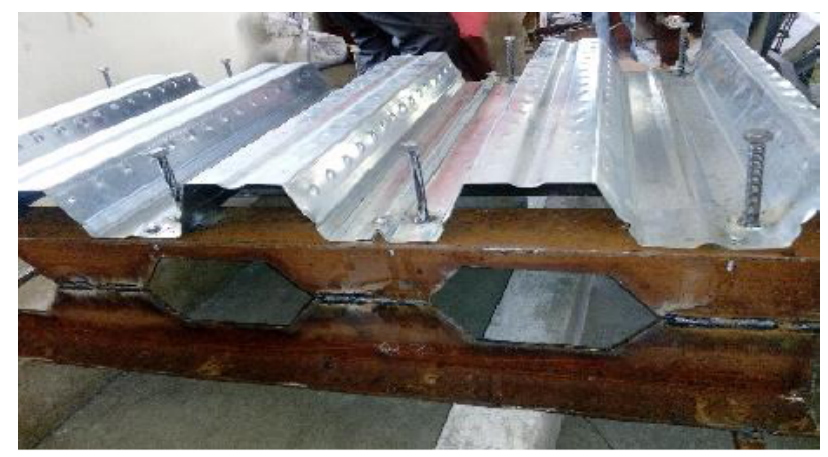

Figure 3.4 Overall deck system

Temperature difference in the slabs is negligible thus there is no need to provide reinforcement to account for temperature stresses. The effect of shrinkage is considered and the total shrinkage strain for design may be taken as 0.003 in the absence of test data, therefore 8 $\mathrm{mm}$ Dia of Fe415 HYSD bar is provided at $150 \mathrm{~mm} \mathrm{c} / \mathrm{c}$ is shown in figure 3.5.

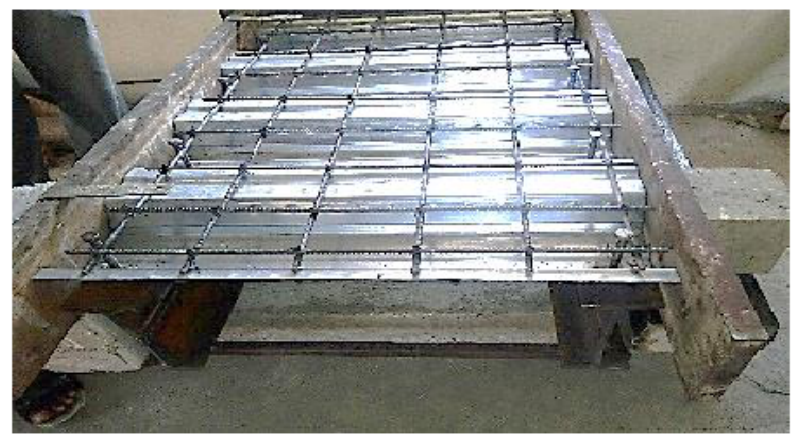

Figure 3.5 Shrinkage reinforcement over profiled sheet

Concrete grade of M30 is engaged in the slab region of composite system, thickness of concrete is maintained over $60 \mathrm{~mm}$ from the crest surface of the steel sheet to the top surface of the slab is displayed in figure 3.6

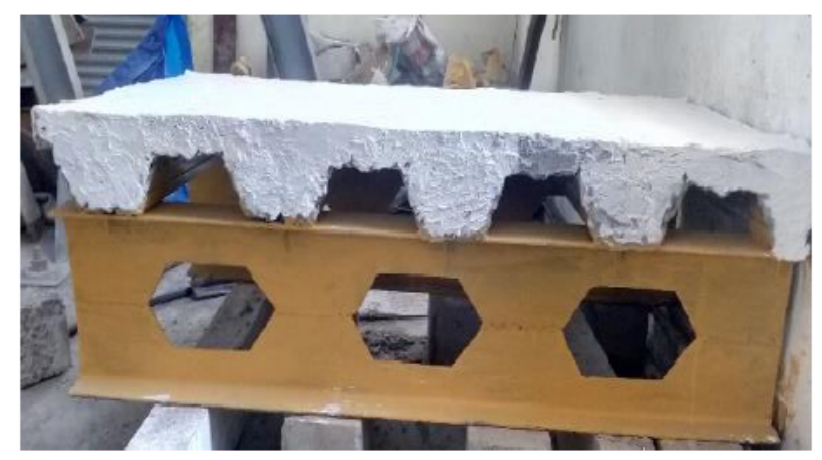

Figure 3.6 Deck system after concreting

Principally in order to find the behavior of castellated beam alone, prototype of same scale which is employed in fabricating for deck system is developed and tested for pure flexure condition. However it is known that behavior of non- composite castellated beams is quite differ from composite castellated beam, so only load deflection part alone is governed and rest of its vierendeel mechanism, shear failure and web rupture are neglected. Moreover composite castellated beams are laterally supported so it overcomes the failure of lateral torsional buckling which usually occurs in non-composite castellated beams. 
Two point load test is carried out on castellated beams and it is subjected to pure flexure condition. Since by manual, loading was unable to apply till it reaches the ultimate load carrying capacity, hence cyclic load of $90 \mathrm{KN}$ is applied and deflection is taken for every $4.5 \mathrm{KN}$ using LVDT and dial gauge is shown in figure 4.1. Equivalent assessment is made on hot rolled section ISMB 200 solid web beam and their load deflection pattern is acquired by applying same sort of cyclic load as done in castellated beam is shown in figure 4.2. The load behavior for both castellated beam and solid I section is discussed in next chapter.

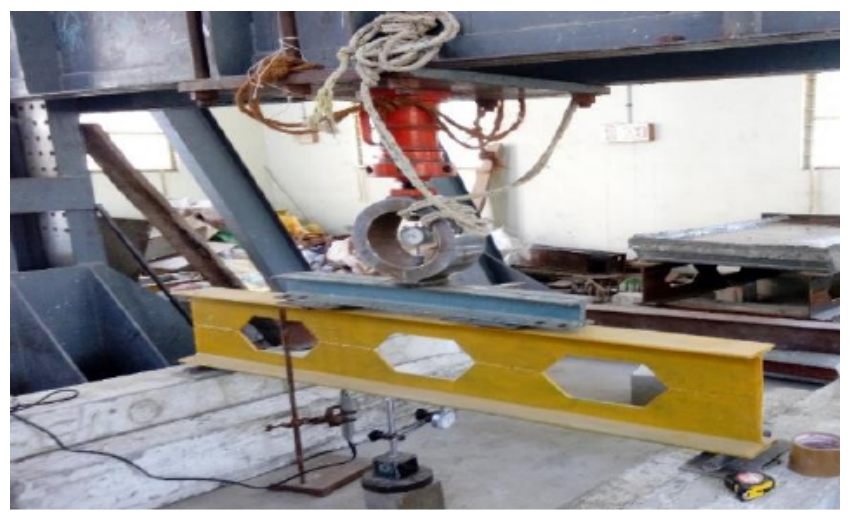

Figure 4.1 Test setup for castellated beam

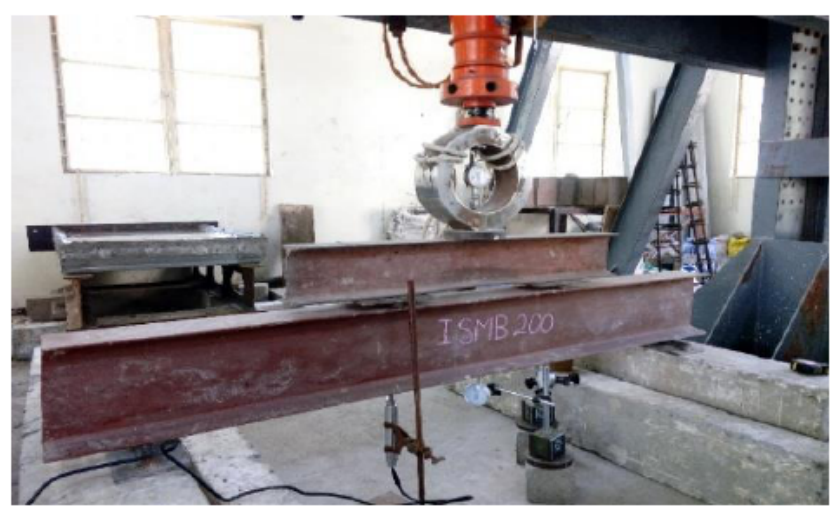

Figure 4.2 Test setup for solid beam

For composite deck slab system, four point loading system is adopted in order to subject the slab to a maximum stress, thus flexural strength and the cracks initiation on the slab can be accurately fixed. This type setup is shown in figure 4.3, where loading is applied through screw jack and proving ring. Both dial gauge and LVDT is fixed at bottom midpoint of the castellated beam and profiled sheet respectively.

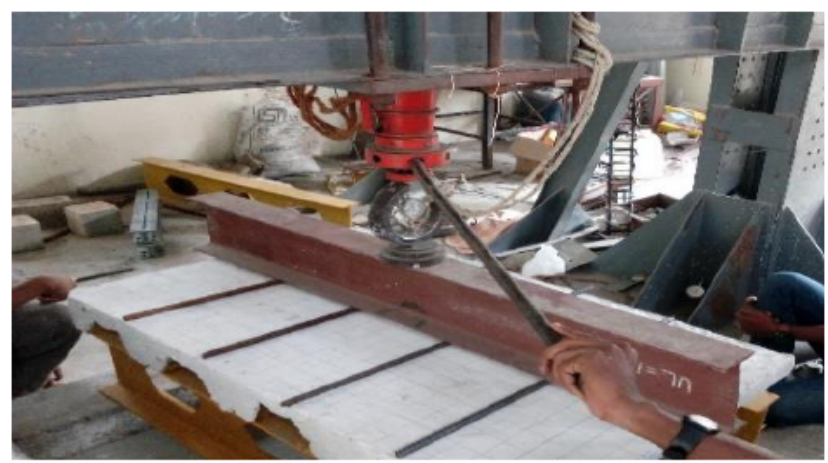

Figure 4.3 Test arrangement for composite slab 


\section{TEST RESULTS}

Since the Solid I section and castellated beams are tested for primary studies, they are subjected to a cyclic load up to its elastic range. So deflection values for each increment of load for every cycle. Both beam test are subjected to load up to $90 \mathrm{KN}$ and their load deflection pattern are shown in figure 5.1, 5.2

From the load deflection curve it has been observed that the deflection of the ISMB 200 is comparatively higher than the castellated beam.

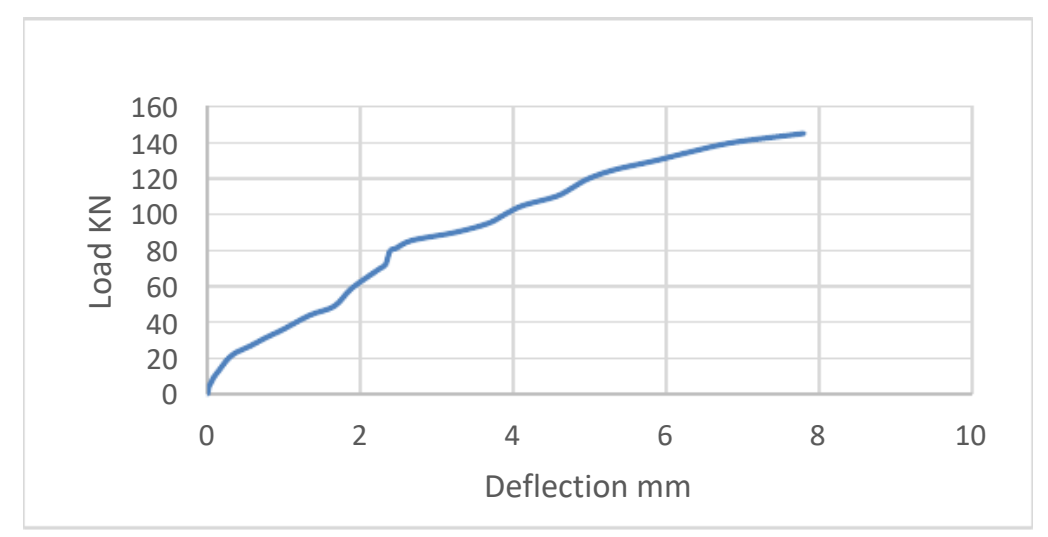

Figure 5.1 Load vs. deflection for solid I section beam

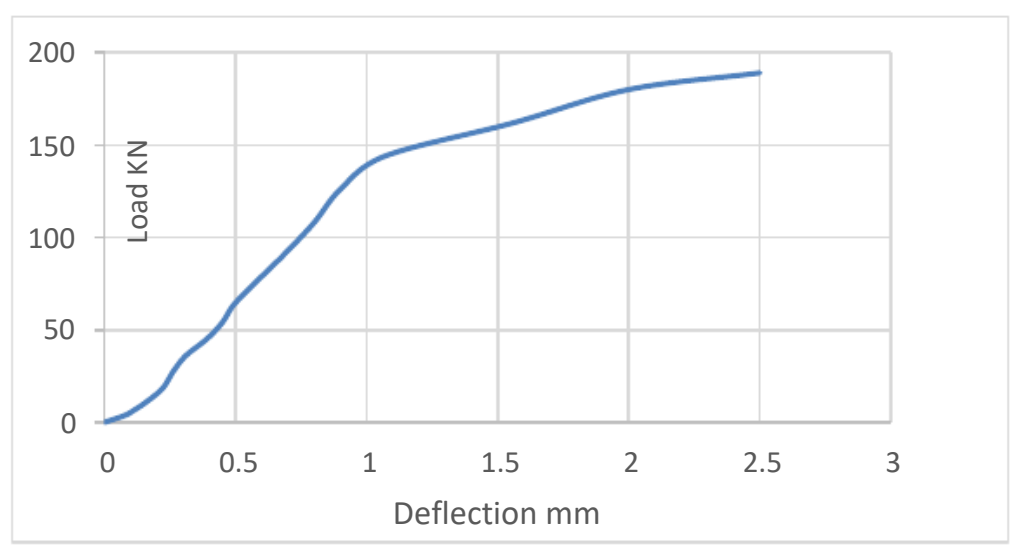

Figure 5.2 Load vs. deflection for castellated beam

Composite Deck Slab

Initial minor crack is witnessed at the load of $180 \mathrm{KN}$. As the load level is increased, delamination starts at the interface of profiled steel sheet and the concrete. At the ultimate load stage delamination becomes significant and that there is a large gap at the interface. The ultimate load carrying capacity of composite deck slab is reached by $216 \mathrm{KN}$. The theoretical load carrying capacity of deck slab is calculated from the bending resistance value and it is founded as $183 \mathrm{KN}$.

The failure pattern of composite deck system is slightly vary from ordinary RCC slab due to usage of decking sheet. When the composite slab reaches its ultimate load carrying capacity, delamination of profiled sheet occurs from the concrete surface usually termed it as interface region. This happens because when the load reaches ultimate limit, the shear connector provided in the composite system fails to bear the upcoming load and the surronding concrete present near the shear connector gets crushed and minimise the composite action of the slab, thereby profiled sheet gets delaminated from the concrete surface. Clear visualization is presented in the below figure.5.3 

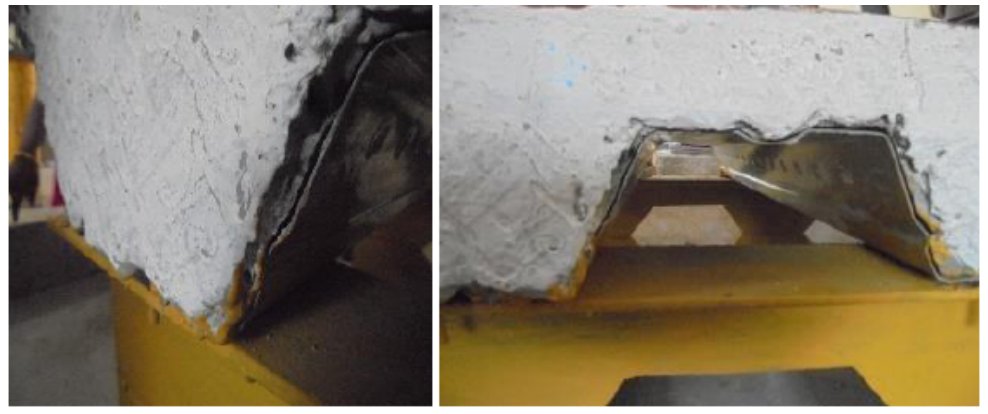

Figure 5.3 Delamination of Profiled sheet

The load deflection curve of the composite deck slab in shown in below figure.5.4.

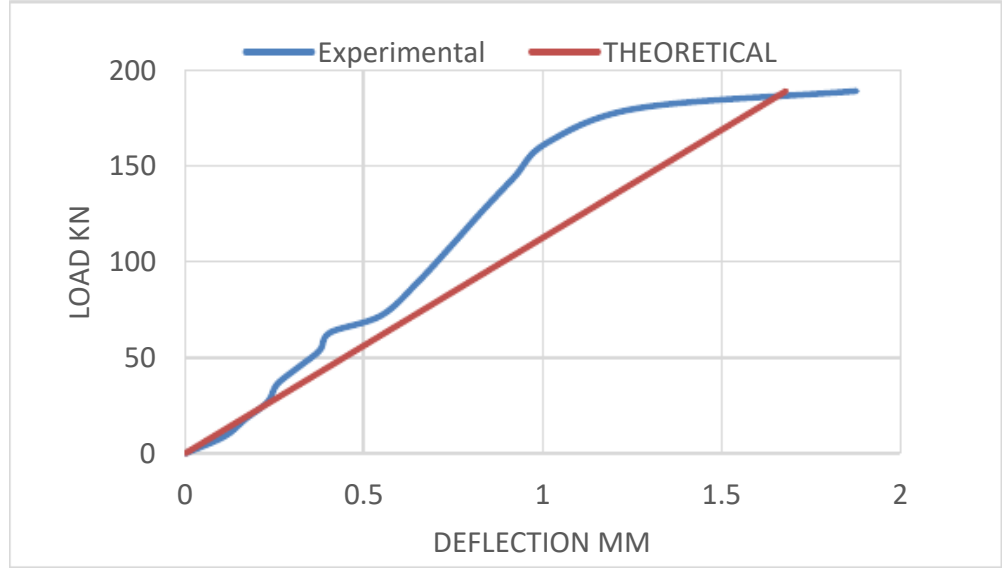

Figure 5.4 Load Vs Deflection curve

\section{CONCLUSION}

When comparison made between ordinary ISMB 200 section and castellated beam of same equal span, deflection of the castellated beam is less due to formation large moment of inertia by increasing depth of beam.

The failure pattern of the composite deck slightly varies from the failure pattern of RCC slab. Overall, by adopting the castellated beam as an intermediate beam for composite deck slab, load carrying capacity, stiffness and energy absorption has been increased. Since the bearing width of the slab is little wider when compared to truss section, deflection of the profiled deck sheet is reduced.

Through the holes present in the castellated section, service pipe lines can be installed which is the basic amenities for most of the industrial and commercial buildings. So this system has exhibits the advantages of both castellated section and composite section in a single platform.

\section{REFERENCES}

[1] Baskar R, Antony Jeyasehar C (2005) "Flexural Behaviour of Composite Deck Slab with and without Embossment" Proceeding of the International conference on Advances in Concrete Composite and Structures, 2005, pp 549-558

[2] Bavan Ma, Shahrizan Bin Baharom and Siti Aminah Osman (2013) "Ultimate Strength of Composite Beam with Web Openings Subjected to Combined Negative Bending and Axial Compression", International Journal of Research in Engineering and Technology, Nov 2013 
[3] Chung K.F, Ko C.H, and Wang A.J (2005) "Design of Steel and Composite beams with web openings-Verification using Finite element Method" Steel and Composite Structures, Vol. 5, No. 2-3, 2005, pp 203-233

[4] Ehab Ellobody and Ben Young (2015) "Nonlinear analysis of composite castellated beams with profiled steel sheeting exposed to different fire conditions", Journal of Constructional Steel Research, Vol.113, 2015, pp 247-260

[5] Hartono W and Chiew, S.P (1995) "Composite behaviour of castellated Beams with concrete top slab", Proceeding of 4th Pacific Structural Steel Conference, Vol.3, pp 69-76

[6] Holomeka J and Bajera M (2012) "Experimental and Numerical Investigation of Composite Action of Steel Concrete Slab", Procedia Engineering, Vol. 40, 2012, pp 143-147

[7] Hyeong-Yeol Kim, Youn-Ju Jeong (2009) "Steel-concrete composite bridge deck slab with profiled sheeting", Journal of Constructional Steel Research Vol.65, 2009, pp1751-1762

[8] Hyeong-Yeol Kim and Youn-Ju Jeong (2010) "Ultimate Strength of a Steel-Concrete Composite Bridge deck Slab with Profiled Sheeting”, Engineer Structures, Vol.32, 2010, pp 534-546

[9] Ismail R.E.S, Fahmy A.S and Twafik N.M (2015) "Finite Element Modelling of Partially Composite Castellated Beam", Communication on Applied electronic, Vol. 2, No. 3, 2015

[10] Ismail R.E.S, Fahmy A.S and Twafik N.M, "Ultimate Behaviour of Composite Castellated Beams under Vertical Loads", International Journal of Computer Applications, Vol. 108, No. 5, 2014

[11] Jawed Qureshi, Dennis Lam and Jianqiao Ye (2011) "The influence of Profiled Sheeting thickness and Shear Connector's position Strength and Ductility of headed Shear Connector", Engineering Structures, Vol. 33, 2011, pp 1643-1656.

[12] Jiang Nie, Jiansheng Fan, and Cai C.S (2015) "Experimental Study of Partially ShearConnected Composite Beams with Profiled Sheeting”, Engineer Structures, Vol. 30, 2008, pp 1-12

[13] Kan Yu-Cheng, Chen L.H, Wu C.H, Tson Yen and Liao H.W (2011) "Composite Behavior of Concrete Slab with Steel Decking under Flexural Loading”, Advanced Materials Research Vols. 284-286, 2011, pp 628-632

[14] Laxmikant Madanmanohar Gupta, Namdeo Adkuji Hedaoo and Girish Narayanrao Ronghe (2012) "Design of composite slabs with profiled steel decking: a comparison between experimental and analytical studies", International Journal of Advanced Structural Engineering, Vol. 3, No. 1, 2012, pp 1-15

[15] Li Liu, Jibin Yi and Fang Wang (2011) "Finite Element Analysis on Profiled Steel Sheet and Concrete Composite Slab", Applied Mechanics and Materials, Vols 94-96, 2011, pp 500-503

[16] Marciukaitis G, Jonaitis B and Valivonis J (2006) "Analysis of Deflections of Composite Slabs with Profiled Sheeting up to the Ultimate moment", Journal of Constructional Steel Research, Vol. 62, 2006, pp 820-830

[17] Marimuthua V, Seetharamana S, Arul Jayachandrana S, Chellappana A, Bandyopadhyayb T.K and Duttab D (2007) "Experimental studies on composite deck slabs to determine the shear-bond characteristic $(m-k)$ values of the embossed profiled sheet", Journal of Constructional Steel Research, Vol. 63, 2007, pp 791-803

[18] Richard Redwood and Soon Ho Cho (1993) "Design of steel and Composite beams with Web Openings", Journal of constructional steel and Research, Vol. 25, 1993, pp 23-41.

[19] Shuo Xu and Tianyu Xiang (2014) "Study on Nonlinear Structural Behaviors of Steel and Concrete Composite Slab”, Advanced Materials Research, Vols.919-921, 2014, pp 602-606 
[20] Tadeh Zirakian and Hossein Showkati (2006) "Distortional Buckling of Castellated Beams", Journal of constructional Steel Research, Vol. 62, 2006, pp 863-871.

[21] Tiago Miguel Cameira Neto (2014), "Analysis and Design of Composite Beams with Web Openings”, Institute Superior Technical 2014.

[22] Widjaja, B.R (1997) “Analysis and Design of steel Deck - Concrete Composite Slabs", Ph.D. thesis, Virginia Polytechnic Institute and State University, USA

[23] Zhaohui Huang, Ian Burgess W and Roger Plank J (2000) "Effective stiffness modelling of composite concrete slabs in fire", Engineering Structures, Vol. 22, 2000, pp 1133-1144.

[24] Akshay Garg, Adhiraj Madhav Dar and Simon Jayasingh, Visuvasam J (2017), Analysis of Composite Sandwich Slabs with Patterned web Reinforcement, International Journal of Civil Engineering and Technology, 8(6),2017, pp. 664-674

[25] Inkwan Paik and Seunguk Na and Sung-Ho Yun, Comparison of Sound Insulation Performance on Two Different Types of Voided Slab Systems, International Journal of Mechanical Engineering and Technology, 9(5), 2018, pp. 612-623. 